\title{
Analisis Tingkat Kepuasan dan Performa pada Merchant OVO di Surabaya
}

\author{
Muhammad Ridho Ar-Robi dan Berto Mulia Wibawa \\ Departemen Manajemen Bisnis, Fakultas Bisnis dan Manajemen Teknologi, \\ Institut Teknologi Sepuluh Nopember (ITS) \\ e-mail: ridhoarrobi20@gmail.com
}

\begin{abstract}
Saat ini, layanan mobile payment di Indonesia telah berkembang, khususnya banyaknya pelaku bisnis yang telah menjadi merchant pada layanan mobile payment di Surabaya. Salah satu layanan mobile payment di Indonesia yang memiliki merchant terbanyak adalah OVO. Saat ini OVO sudah memiliki sekitar 300.000 merchant yang tersebar di seluruh Indonesia, salah satunya adalah Surabaya. Tujuan dari penelitian ini adalah untuk mengetahui klasifikasi usaha yang sesuai dalam menggunakan layanan mobile payment sehingga dapat meningkatkan kepuasan dan performa bagi merchant OVO. Pada penelitian ini melakukan penyebaran kuesioner langsung kepada setiap merchant OVO yang terdapat di berbagai wialayah Surabaya. Jumlah responden yang didapatkan sebesar 180 merchant, dengan kriteria merchant pengguna OVO di Surabaya dalam kurun waktu satu bulan. Jumlah responden yang didapatkan telah sesuai dengan yang ditargetkan. Untuk tujuan tersebut dapat diselesaikan menggunakan metode ANOVA. Berdasarkan hasil dari uji ANOVA menyatakan bahwa tidak ada perbedaan data yang didapatkan pada kelompok merchant yang berada di kelompok usaha mikro kecil dan usaha menengah atas, sehingga dapat disimpulkan bahwa semua kelompok usaha dapat menggunakan OVO untuk meningkatkan performanya.
\end{abstract}

Kata Kunci-ANOVA, Kepuasan Pengguna, Merchant, Performa.

\section{PENDAHULUAN}

$\mathrm{F}$ ENOMENA pertumbuhan internet membentuk adanya revolusi digital di dunia (Republika, 2017). Salah satu negara dengan pengguna internet terbanyak nomer enam di dunia adalah Indonesia [1]. Adanya pembentukan revolusi digital ditandai dengan hasil Lembaga riset digital marketing E - marketer yang memperkirakan pada 2018 jumlah pengguna aktif smartphone di Indonesia lebih dari 100 juta orang[1]. Fenomena ini dimanfaatkan oleh platform bisnis di Indonesia yang menjadikan jaringan sebagai core bisnisnya seperti Tokopedia, Bukalapak, online store yang hadir melalui social media dan sebagainya. Bank Indonesia memperkirakan ada 24,7 juta orang yang melakukan belanja online serta jumlah nilai transaksi dari belanja online tersebut diprediksi mencapai Rp 144 triliun pada 2018, naik dari Rp 69,8 triliun di 2016 dan Rp 25 triliun di 2014 [2]. Tren tersebut menciptakan metode pembayaran baru di Indonesia yang bernama Financial Technology (Fintech). Fintech merupakan gabungan antara jasa keuangan dengan teknologi yang mengubah model bisnis dari konvensional menjadi moderat. Salah satu bentuk fintech yang menjadi tren saat ini adalah mobile payment.

Mobile payment sendiri merupakan alat transaksi yang dilakukan antara pembeli dan merchant dengan menggunakan alat bantu elektronik sebagai instrumen pembayaran [3]. Merchant adalah penjual barang atau jasa yang memiliki bentuk usaha (physical store) maupun online store yang bekerjasama dengan layanan mobile payment dalam penyediaan layanan penerimaan pembayaran melalui mobile payment yang bersangkutan. Pada market mobile payment yang menjadi segmen dan end user adalah merchant dan konsumen [4]

Merchant hadir tidak lepas dari munculnya berbagai layanan mobile payment di Indonesia. Pada tahun 2012 layanan mobile payment mulai beragam, industri perbankan dan pengembang aplikasi mulai masuk di dalamnya. Salah satunya adalah OVO. Untuk memperluas dan memajukan perekonomian negeri, OVO bekerja sama dengan para Usaha Mikro Kecil dan Menengah (UMKM) untuk menggunakan layanan mobile payment OVO Indonesia. Tercatat hingga saat ini lebih dari 9000 merchant OVO dengan latar belakang UMKM [5]. Namun, permasalahan yang terjadi dari sisi informasi, sistem dan pelayananya yang masih kurang membuat para merchant dengan latar belakang UMKM belum siap untuk menghadapi pembayaran digital. Hal ini ditandai dengan masih rendahnya minat UMKM yang menggunakan layanan mobile payment sebagai alat pembayaran berbasis digital yaitu sebesar 3\% dari jumlah merchant yang bergabung sebagai mitra dari OVO Indonesia.

Maka dari itu, berdasarkan permasalahan di atas pada penelitian ini ingin melihat tingkat kepuasan dan performa individu yang ada pada merchant dalam menggunakan layanan mobile payment OVO berdasarkan latar belakang usaha merchant OVO di Surabaya.

\section{II.LANDASAN TEORI}

\section{A. Perilaku Konsumen}

Konsumen adalah seseorang yang menggunakan produk atau jasa [6]. Konsumen merupakan individu yang membeli produk atau jasa dari orang lain untuk digunakan oleh individu tersebut sebagai bentuk kebutuhan. Setiap konsumen memiliki pola perilaku yang berbeda - beda terhadap suatu produk atau jasa yang mereka gunakan biasa dinamakan perilaku konsumen. Perilaku konsumen adalah suatu bentuk pelajaran atau studi mengenai seseorang, kelompok, dan organisasi dalam hal memilih, membeli, menggunakan dan mengevaluasi produk atau jasa untuk memenuhi kebutuhannya [7].

Perilaku konsumen dapat berubah seiiring berjalannya waktu. Saat ini salah satu faktor terbesar dalam perubahan perilaku konsumen adalah teknologi. Teknologi merupakan hal yang dapat merubah perilaku suat individu, kelompok maupun organisasi. Salah satunya melalui fenomena pertumbuhan internet yang membentuk adanya revolusi digital di dunia. Hal ini tentunya memciptakan perilaku 
konsumen berubah kearah online dimana konsumen mengandalkan internet dalam kegiatan sehari - harinya seperti mencari informasi, pembelanjaan dan sebagainya. Perubahan perilaku konsumen yang bergerak kearah online menciptakan layanan baru yaitu mobile payment.

\section{B. DeLone and McLean Model}

Model ini digunakan untuk mengevaluasi information System (IS) yang digunakan yaitu mobile payment terhadap kepuasan dan performa penggunanya. Model DeLone \& McLean termasuk dalam IS Success model [8]. Dalam model DeLone and McLeand dapat mengidentifikasi kategori yang digunakan untuk melihat keberhasilan suatu sistem dengan memetakan aspek keberhasilan IS ke setiap tingkat efektivitas [9]. Hal tersebut dapat dilihat berdasarkan mathematical theory of communication pada IS yaitu tingkat teknis, tingkat semantic, dan yang terakhir adalah tingkat efektivitas [8]. Penambahan kualitas pelayanan sebagai komplemen dari kedua tingkatan sebelumnya yaitu kualitas informasi dan kualitas sistem [10]. Hal ini menjadi salah satu strategi pemasaran untuk meningkatkan kepuasan pengguna [7]. Selain itu, ketiga konstruk tersebut dinilai sebagai kunci utama dalam menerapkan sebuah system. Sehingga pada penelitian ini, dengan mengadopsi model DeLone \& McLean yang menilai kepuasan pengguna, dan performa.

\section{Kepuasan Pengguna}

Kepuasan atau satisfaction merupakan perasaan senang atau ketidak senangan dari seseoarang atau pengguna yang muncul setelah membandingkan hasil suau produk atau jasa yang digunakan terhadap hasil yang diharapkan [7]. Selain itu, kepuasan merupakan suatu sikap yang dibentuk berdasarkan pengalaman yang didapatkan dari suatu produk atau jasa ketika menggunakan [11]. Kepuasan pengguna (ST) merupakan bentuk evaluasi dari pengguna ketika menggunakan Information System (IS) tersebut [12]. Pada penelitian - penelitian terdahulu menyatakan bahwa kepuasan pengguna merupakan hal yang dapat mengukur suatu keberhasilan dari IS yang digunakan [13]

Pada penelitian terdahulu yang dilakukan menyatakan tingkat penjualan pada suatu perusahaan yang menjual produk atau jasa dapat dipresentativkan melalui tingkat kepuasan dari penggunanya [14]. Dalam pengukuran kepuasan pengguna dapat dilakukan melaui kepuasan pengguna secara keseluruhan ketika pengguna menggunakan IS tersebut [15].

\section{D.Performa}

Performa (PF) merupakan hasil atau dampak dari kepuasan pengguna dan kegunaan yang dirasakan dari sebuah system yang digunakan [12]. Bagaimanapun, dampak yang diterima dari IS yang digunakan dapat mengidikasikan pengguna merasa lebih baik ketika menggunakannya. Dalam penggunaanya, pengguna dapat meningkatkan produktivitas dalam hal pengambilan keputusan. Selain itu dapat menghasilkan perubahan dalam aktivitas pengguna. Untuk mengukur tingkat performa dari pengguna ketika menggunakan IS, dapat dilihat dari beberapa variabel pengukur yaitu tingkat kepercayaan diri pengguna, efisiensi pengguna, waktu pengerjaan tugas pengguna ketikan menggunakan IS tersebut dan beberapa variabel lainnya [15]

Pada penelitian ini untuk mengukur performa dari penggunaan layanan mobile payment OVO Indonesia menggunakan tiga variabel pengukur yaitu kecepatan pengguna dalam menyelesaikan tugasnya ketika menggunakan OVO Indonesia, kemudahan bagi pengguna ketika menyelesaikan pekerjaan menggunakan OVO Indonesia, dan kecepatan waktu pengerjaan bagi pengguna layanan mobile payment OVO Indonesia dalam menyelesaikan tugasnya yang diadopsi dari penelitian terdahulu [8]

\section{METODE PENELITIAN}

\section{A. Desain Penelitian}

Penelitian ini menggunakan pendekatan riset deskriptif, dimana memiliki tujuan utama untuk mengidentifikasi karakteristik perilaku merchant OVO dalam menggunakan layanan mobile payment OVO di Surabaya. Data yang diambil pada penelitian ini menggunakan data primer, dimana data tersebtu didapatkan dari hasil survey kuesioner pada merchant OVO di Surabaya.

\section{B. Sampel}

Populasi merupakan suatu wilayah yang terdiri atas objek atau subjek yang memunyai kualitas dan karakteristik tertentu yang ditetapkan oleh peneliti untuk dipelajari untuk menyelesaikan permasalahan di dalam penelitian ini [16]. Sampel merupakan bagian dari populasi. Kirteria sampel yang digunakan pada penelitian ini adalah merchant pengguna OVO Indonesia di Surabaya yang sudah menggunakan OVO Indonesia dalam kurun waktu penggunaan mencapai satu bulan. Dalam pengambilan sampel penelitian, dalam penelitian menggunakan teknik atau metode multiple cross sectional. Metode tersebut merupakan teknik dengan pegambilan sampel dua bahkan lebih responden, dan infromasi yang didapat dari setiap responden hanya satu kali [17]. Sampel yang digunakan dan diolah dalam penelitian ini sudah melewati screening, sehingga hasil yang didapat akan sesuai jika dilakukan uji asumsi. Jumlah sampel yang digunakan dalam penelitian ini adalah 180 merchant. Hal ini dikarenakan besar sampel yang disarankan adalah sebesar 5 sampai dengan 10 kali jumlah indicator variabel yang digunakan dalam penelitian [18].

\section{C.Metode Analisis Data}

Cross tabulation merupakan metode yang digunakan untuk melihat suatu hubungan dalam dua variabel atau lebih yang bersifat kuantitatif [16]. Selain itu metode cross tabulation digunakan untuk mengethaui hubungan antara variabel berbasis baris dan kolom secara statistik. Pada penelitian ini dilakukan analisis mengenai mengenai metode cross tabulation untuk mengetahui karakteristik merchant dalam penggunaan mobile payment $\mathrm{OVO}$ Indonesia. Berikut adalah daftar analisis cross tabulations yang dilakukan pada penelitian ini.

1. Lama usaha berdiri - Lokasi tempat usaha - Waktu penggunaan OVO

2. Jenis usaha - Omset usaha perbulan - Frekuensi penggunaan $\mathrm{OVO}$

3. Jenis usaha - Lama usaha berdiri - Alasan menggunakan OVO

Metode ANOVA merupakan teknik analisis statistik yang digunakan untuk menguji dua kelompok atau lebih yang berasal dari populasi penelitian. ANOVA merupakan teknik statistik yang digunakan untuk memeriksa perbedaan diantara sarana untuk menguji dua atau lebih populasi yang ada pada penelitian [17]. Fungsi dari analysis of variance (ANOVA) untuk melihat tingkat dari signifikansi variabel yang digunakan pada penelitian dilihat dari perbandingan kelompok sambel yang digunakan [18]. Selain itu analisis 
varians merupakan metode analisis statistik yang dapat menguji hipotesis penelitian pada perbedaan antara dua atau lebih dari kelompok populasi.

ANOVA dapat dianggap sebagai analisis faktortial yang tergolong akurat dalam proses analisis varians. ANOVA terbagi menjadi dua kategori yaitu one - way dan two - way [17]. Analisis one - way merupakan analisis varians yang menguji ekuitas dari rata - rata populasi ketika terklasifikasi dengan satu variabel. Sedangkan untuk analisis two - way merupakan analisis varians yang menguji ekuitas dari rata - rata populasi ketika terklasifikasi dengan dua variabel yang diuji.

Pada penelitian ini menggunakan kategori one - way ANOVA. Hal ini dikarenakan ingin mengetahui tingkat signifikansi dari klasifiksi usaha merchant yang terbagi dalam tingkatan UMKM terhadap variabel kepuasan pengguna dan performa. Dalam penilian signifikansi, cut of value nya sebesar 0,05 .

\section{ANALISIS DAN DISKUSI}

\section{A. Analisis Data}

Pada penelitian ini, jumlah data yang digunakan sebesar 180 berdasarkan jumlah yang didapatkan dari hasil penyebaran kuesioner. Penyebaran kueisoner dan pencarian responden dilakukan oleh peneliti sendiri. Dalam pengisian kuesioner, peneliti mengisi sendiri setiap bagian yang ada pada kuesioner dengan membacakan pertanyaan kepada salah satu pegawai merchant OVO. Penyebaran kuesioner ini dilakukan melalui media offline. Penyebaran kuesioner offline dilakukan oleh peneliti di tempat usaha merchant. Penyebaran dilakukan di wilayah Surabaya dengan mendatangi pusat perbelanjaan yang tersebar di wilayah Surabaya. Pada penelitian ini menggunakan bagian dari teknik probability sampling, yang berarti seluruh elemen yang ada didalamnya memiliki peluang dan kemungkinan yang sama untuk dipilih menjadi sampel pada penelitian ini [17]. Pada penelitian ini bertujuan untuk mengetahui karakteristik dan tingkat perbedaan kepuasan dan performa yang dirasakan oleh merchant ketika menggunakan layanan mobile payment OVO. Sehingga tujuan tersebut dapat diketahui melalui analisis cross tabulation dan ANOVA. Pada penelitian ini menguji tiga cross tabulation.

1) Analisis Cross Tabulation

Cross tabulation 1 - Pada analisis cross tabulation yang pertama memberikan informasi mengenai hubungan antara lama berdirinya usaha merchant, tempat usaha merchant dengan lama waktu penggunaan OVO hingga saat ini. Berdasarkan hasil olah data yang dilakukan ditemukan bahwa mayoritas pengguna OVO terlama dengan kurun waktu penggunaan sudah mencapai 10 sampai 12 bulan adalah merchant yang usahanya telah berdiri selama kurun waktu lebih dari 10 tahun. Jumlah merchant tersebut mencapai 26 merchant, dimana lokasinya berada di wilayah Surabaya Pusat. Hal ini menandakan pusat perekonomian di Surabaya berkembang dari wilayah pemerintahan Kota Surabaya yang berada di Surabaya Pusat. Selain itu, hasil tersebut menandakan merchant yang sudah bergabung di OVO sejak lama memiliki strategi yang tepat untuk mempertahankan usahanya di zaman yang terus berkembang, hal ini didukung oleh letak geografis mereka yang berada di pusat kota Surabaya. Sehingga perusahaan yang baru mendirikan usaha di Surabaya seperti OVO, tentunya melakukan pilot test di daerah Surabaya Pusat. Selain itu jika dilihat dari hasil cross tabulation yang dilakukan, penyebaran pengguna OVO di daerah Surabaya sudah hampir merata. Hal ini menandakan OVO sudah dapat diterima oleh usaha - usaha yang ada di daerah Surabaya. Peran pemerintah, bagi OVO dan merchant menjadi hal yang penting untuk bersinergi menjadikan perekonomian yang meningkat di Surabaya, dan program pemerintah untuk memberlakukan cashless society dapat terwujud.

Cross tabulation 2 - Pada analisis cross tabulation kedua yang dilakukan memberikan informasi mengenai hubungan antara jenis usaha merchant, omset usaha yang diterima merchant dalam kurun waktu satu bulan dengan frekuensi konsumen perhari yang membayar menggunakan OVO. Berdasarkan hasil olah data yang dilakukan dapat diketahui bahwa konsumen lebih sering membayar menggunakan OVO pada bidang usaha makanan dan minuman yang mencapai jumlah 81 dari total responden, dimana usaha makanan dan minuman tersebut tergolong dalam usaha kecil. Selain itu pada usaha makanan dan minuman, satu merchant dapat melayani konsumen yang membayar menggunakan OVO dapat mencapai 40 sampai dengan 55 kali transaksi pada klasifikasi usaha kelas menengah.

Hasil ini tentu sesuai karena usaha tersebut memiliki tingkat kepercayaan yang tinggi dan juga sudah memiliki brand awareness yang tinggi dimata masyarakat Surabaya. Apalagi makanan dan minuman merupakan produk fast moving, sehingga konsumen sedapat mungkin dapat lebih cepat mendapatkan produk tersebut. Maka dari itu pada hasil ini produk makanan dan minuman memiliki jumlah pengguna terbanyak dalam penggunaan layanan mobile payment OVO sebagai media transaksi mereka. Selain itu berdasarkan hasil yang dilakukan pada crosstabulation kedua ini dapat dilihat sector industry di Surabaya sudah mulai menggunakan OVO sebagai media transaksi mereka dan tentunya para usaha yang berada pada klasifikasi UMKM di Surabaya sudah menggunakan OVO terutama pada bidang usaha makanan dan minuman. Hal ini menandakan bahwa para pelaku usaha di Surabaya sudah faham untuk terus berkembang dengan mengikuti tren bisnis saat ini khususnya di bidang layanan mobile payment.

Cross tabulation 3 - Pada analisis cross tabulation ketiga yang dilakukan memberikan informasi mengenai hubungan antara bidang usaha yang dijalani oleh merchant, lama usaha berdiri dengan alasan merchant menggunakan layanan mobile payment OVO. Berdasarkan hasil yang didapatkan, diketahui bahwa bidang usaha makanan dan minuman serta pakaian dan juga retail menjadi usaha dengan waktu berdiri yang sudah lama. Usaha tersebut berdiri rata - rata sudah 10 tahun keatas, sehingga untuk mempertahankan bisnisnya mereka menggunakan layanan mobile payment OVO untuk menjangkau konsumen pengguna OVO. Hal ini tentunya merupakan strategi yang baik yang dilakukan oleh pelaku usaha tersebut.

Selain itu pada hasil ini didapatkan informasi dari ke lima bidang jenis usaha, dan lama waktu usaha berdiri alasan yang mereka pilih adalah kemudahan transaksi. Sehingga OVO diharapkan dapat membantu mereka dalam menyelesaikan tugas mereka lebih mudah. Ketika ekspektasi merchant tersebut sesuai nantinya merchant dapat merasakan kepuasan dari penggunaan layanan mobile payment OVO. Pada cross tabulation ketiga ini juga diketahui bahwa alasan untuk menggunakan OVO pada kelima bidang usaha tersebut yang baru berdiri adalah ingin usahanya dapat menjangkau konsumen pengguna OVO. Hal ini dikarenakan adanya promo cashback yang diberikan kepada konsumen serta kecepatan yang dapat dirasakan merchant ketika menggunakan OVO. 


\section{2) ANOVA}

Pada pengujian ANOVA, nilai signifikansi yang didapatkan merupakan acuan dalam menilai ada atau tidaknya perbedaan yang signifikan anatara kelompok merchant yang terbagi dalam klasifikasi UMKM, dilihat dari omset usaha perbulan. Untuk nilai minimum atau cut of value nya adalah 0,05. Apabila nilai signifikansi dibawah 0,05 maka terdapat perbedaan data yang siginifikan pada kelompok tersebut, namun jika nilai tersebut diatas nilai 0,05 maka tidak ada perbedaan data yang signifikan diantara kelompok tersebut.

Tabel 1.

Hasil ANOVA

\begin{tabular}{llccc}
\multicolumn{5}{c}{ Hasil ANOVA } \\
\hline \hline No. & Variabel & Mean & Mode & Sig. \\
\hline 1 & Kepuasan pengguna & 3.65 & 4,00 & 0,85 \\
2 & Performa & 3.72 & 4,00 & 0,61 \\
\hline \hline
\end{tabular}

\section{B. Diskusi}

Berdasarkan hasil uji ANOVA dapat dilihat nilai signifikansi yang didapatkan sebesar 0,85 dan 0,61 (Tabel 1). Maka dari itu tidak ada perbedaan signifikan antara usaha mikro, kecil, menengah dan atas dalam menggunakan layanan mobile payment OVO yang dilihat melalui tingkat kepuasan dan performa merchant. Maka dari itu hipotesis keduanya ditolak.

Jika dilihat dari nilai modus yang sering muncul, merchant merasa puas dengan tingkat efektifitas, esfiesnsi, serta puas secara keseluruhan dalam menggunakan layanan mobile payment OVO. Sedangkan ada gap yang terjadi jika dilihat menggunakan nilai mean pada kedua variabel kepuasan pengguna dan performa. Sehingga ada beberapa merchant yang merasa tidak setuju ataupun cukup setuju dengan kepuasan dan performa yang dirasakan ketika menggunakan layanan mobile payment OVO. Maka dapat dikatakan merchant dengan berlatar belakang usaha mikro, kecil, menengah dan usaha kelas atas sama sama merasakan tingkat kepuasan dan performa yang sama ketika mereka menggunakan layanan mobile payment OVO. Sehingga OVO dirasa cocok untuk digunakan sebagai alat transaksi bagi pelaku usaha dari yang tergolong usaha mikro sampai usaha yang sudah besar.

\section{C.Implikasi Manajerial}

\section{1). Berdasarkan Analisis Cross Tabulation}

Implikasi manajerial dari analisis cross tabulation didapatkan dua temuan yang menarik. Kedua temuan tersebut adalah merchant yang menjual produk makanan dan minuman memiliki tingkat frekuensi yang lebih tinggi dan temuan berikutnya adalah merchant dengan penggunaan OVO terlama adalah merchant yang berada di daerah Surabaya pusat. Implikasi manajerial pada temuan pertama adalah pemberian point yang dapat berubah menjadi reward bagi merchant yang berhasil memperoleh konsumen terbanyak per harinya sesuai dengan pengelompokkan merchant yang ditentukan oleh perusahaan. Dimana nantinya setiap merchant dapat berkompetisi dengan baik untuk meraih konsumen terbanyak sesuai dengan klasifikasinya masing - masing dan jumlah merchant yang memiliki tingkat frekuensi perharinya akan mendapatkan point. Point tersebut nantinya dapat ditukarkan reward yang diberikan oleh pihak OVO. Program ini diharapkan merchant memiliki tingkat frekunesi yang seimbang dalam klasifikasnya. Semakin tinggi tingkat frekuensi penggunaan menandakan jumlah konsumen yang membayar melalui OVO semakin meningkat. Dampaknya akan berdampak positif bagi merchant maupun OVO.

Selanjutnya, untuk program yang diberikan berdasarkan hasil temuan kedua terdiri dari tiga program. Program pertama adalah pihak OVO melakukan pendekatan ke toko - toko yang berada di wilayah Surabaya lainnya dengan cara melakukan event marketing. Program kedua adalah pihak OVO melakukan pendekatan ke berbagai komunitas usaha yang ada di Surabaya. Dan program terakhir adalah bekerja sama dengan pemerintah Kota Surabaya dalam bentuk peningkatan jumlah UMKM dan usaha yang adai di Surabaya untuk menggunakan layanan mobile payment OVO. Ketiga program tersebut memiliki tujuan yang sama yaitu adalah meningkatkan pengguna OVO dari sisi merchant di Surabaya. Dengan adanya penggunaan mobile payment tentunya akan mendorong konsumen pengguna OVO untuk membeli di merchant OVO. Semakin banyak dan tersebarnya pengguna OVO di Surabaya tentunya akan meningkatkan kemudahan konsumen dalam menjangkau merchant yang menggunakan OVO, karena sudah tidak terpusat di wilayah Suarabaya pusat.

2). Berdasarkan ANOVA

Berdasarkan uji ANOVA maka ditemukan temuan yang menarik. Dimana pada hasil uji ANOVA tidak ada perbedaan data yang signifikan diantara merchant yang tergolong dalam usaha mikro, kecil, menengah dan atas terhadap tingkat kepuasan dan performa. Berdasarkan nilai modus yang sering muncul, merchant merasa puas dengan tingkat efektifitas, esfiesnsi, serta puas secara keseluruhan dalam menggunakan layanan mobile payment OVO. Hasil tersebut juga terdapat dalam variabel performa. Maka dapat dikatakan merchant dengan berlatar belakang usaha mikro, kecil, menengah dan usaha kelas atas sama sama merasakan tingkat kepuasan dan performa yang sama ketika mereka menggunakan layanan mobile payment OVO.

Berdasarkan temuan tersebut pada penelitian ini merekomendasikan program marketing yang dapat dilakukan oleh pihak OVO yaitu mengadakan event marketing seperti seminar ataupun workshop yang mengundang pemilik dari merchant dengan pemilik toko toko dan UMKM di Surabaya. Tujuan dari acara ini adalah membentuk opinion leader dari merchant yang sudah bekerjasama dengan OVO. Targetnya adalah usaha - usaha yang ada di Surabaya khususnya UMKM yang belum menggunakan layanan mobile payment OVO sebagai instrument pembayaran. Harapannya adalah dengan adanya kegiatan tersebut, merchant yang sudah bergabung dapat meyampaikan bahwa mereka puas atas layanan mobile payment OVO dan penggunaan OVO dapat membantu meningkatkan performa merchant. Sehingga dengan adanya ini para usaha yang ada di Surabaya khususnya UMKM mampu bergabung menjadi merchant OVO.

Selanjutnya program yang dibentuk berdasarkan temuan dari ANOVA adalah perusahaan dapat Membuat content success story dari para merchant dengan latar belakang UMKM yang sudah tergabung di Surabaya. Content tersebut disebar kan melalui media sosial, booklet serta media masssa seperti koran yang bertemakan bisnis. Program ini untuk mendukung program sebelumnya ketika pihak OVO melakukan pendekatan ke berbagai UMKM dan pelaku bisnis di Surabaya. Tujuannya adalah memberikan bukti nyata kepada para UMKM dan pelaku bisnis di Surabaya bahwa ketika mereka bergabung menjadi OVO, usaha tersebut dapat maju. Hal ini dikarenakan adanya bukti yang menjadi opinion leader dari merchant yang sudah menjadi sukses. Selain itu, program ini untuk 
membentuk trust bagi perusahaan di benak UMKM dan pelaku bisnis di Surabaya. Sedangkan untuk program yang terakhir adalah pihak OVO dapat membentuk komunitas dari merchant yang tergabung. Tujuannya adalah untuk memberikan wadah bagi pelaku bisnis dan UMKM yang tergabung sebagai merchant OVO di Surabaya dapat berkumpul untuk menambah relasi dan hubungan baik antar merchant tersebut. Selain itu mereka dapat sharing atas bisnis yang mereka jalankan, terutama para UMKM yang dapat belajar dengan usaha yang tergolong dalam usaha kelas atas dengan omset yang sudah mencapai miliyaran perbulannya. Tentunya program ini dapat menjaga hubungan baik diantara merchant dan pihak layanan mobile payment khhususnya OVO.

\section{V.SIMPULAN DAN SARAN}

\section{A. Simpulan}

Tingkat kepuasan dan performa yang dirasakan oleh merchant yang berada di kelompok usaha mikro, kecil, menengah dan atas adalah sama. Hal ini berdasarkan uji one-way ANOVA dimana nilai singnifikansi nya berada diatas nilai 0,05. Maka dari itu semua kelompok usaha mulai dari usaha mikro sampai dengan usaha menegah atas dapat menggunakan layanan mobile payment OVO.

\section{B. Limitasi dan Saran}

Pada penelitian ini terdapat beberapa keterbatasan. Keterbatasan ada pada merchant OVO yang dijadikan responden hanya ada di Surabaya saja dan didominasi oleh wilayah Surabaya pusat dan timur. Selain itu, mayoritas merchant yang menjadi responden pada penelitian ini tergolong dalam usaha kecil. Hal ini terjadi dikarenakan keterbatasan akses peneliti untuk melakukan penyebaran kuesioner di pusat perbelanjaan yang ada di wilayah lainnya dan mendapatkan izin dari usaha yang tergolong dalam usaha kelas atas. Selain itu pada penelitian ini tidak mengetahui jumlah real dari merchant OVO di Surabaya. Hal ini dikarenakan keterbatasan akses ke perusahaan yang tidak memberikan informasi mengenai hal tersebut.

Saran untuk penelitian selanjutnya adalah perusahaan objek yang diamati tidak hanya satu tetapi dapat terdiri dari beberapa perusahaan penyedia layanan mobile payment OVO sehingga dapat membandingkan tingkat kepuasan yang dirasakan oleh merchant. Selain itu pada penelitian selanjutnya apabila di Surabaya, dapat mengeskplor wilayah lain seperti di wilayah Surabaya selatan, barat dan utara ataupun cakupan dari penelitian yang diperbesar menjadi tingkat provinsi di jawa timur ataupun menggunakan skala nasional yaitu penelitian terhadap merchant pengguna layanan mobile payment di Indonesia. Selain itu saran kepada penelitian selanjutnya adalah dapat menambah jumlah responden yang diteliti.

\section{DAFTAR PUSTAKA}

[1] Kominfo, "indonesia-raksasa-teknologi-digital-asia," 2015. .

[2] Liputan 6, "transaksi-e-commerce-indonesia-akan-capai-rp-144triliun.," $2017 . \quad$ [Online]. Available: https://www.liputan6.com/tekno/read/3057134/2018-transaksi-ecommerce-indonesia-akan-capai-rp-144-triliun.

[3] J. Apanasevic , T., \& Markendahl, "Stakeholders' expectations of mobile payment in retail: lessons from Sweden.," Int. J. Bank Mark., pp. 37-61, 2016.

[4] B. F. Hayashi and T. Bradford, "Mobile Payments: Merchants , Perspectives," pp. 33-58.

[5] Kompas, "melihat-strategi-open-platform-ala-ovo," 2018. [Online]. Available:

https://ekonomi.kompas.com/read/2018/05/28/090900226/melihatstrategi-open-platform-ala-ovo.

[6] S. L. Zainal, Ridho, Fadila, and Dewi, Perilaku Konsumen. Palembang: Citrabooks, 2013.

[7] Kotler and Keller, Manajemen Pemasaran, 13th ed. Jakarta: Erlangga, 2009.

[8] C. Tam and T. Oliveira, "Understanding the impact of $m$-banking on individual performance: DeLone \& McLean and TTF perspective," Comput. Human Behav., vol. 61, pp. 233-244, 2016.

[9] S. Petter and E. R. McLean, "A meta-analytic assessment of the DeLone and McLean IS success model: An examination of IS success at the individual level," Inf. Manag., vol. 46, no. 3, pp. 159-166, 2009.

[10] B. Kim, "An empirical investigation of mobile data service continuance: Incorporating the theory of planned behavior into the expectation-confirmation model," Expert Syst. Appl., vol. 37, no. 10, pp. 7033-7039, 2010.

[11] J. Wirtz, Services Marketing: People, Technology, Strategy BOOK in JOURNAL OF SERVICES MARKETING, no. February. 2011.

[12] T. M. Lee and C. Park, "Mobile technology usage and B2B market performance under mandatory adoption," Ind. Mark. Manag., vol. 37, no. 7, pp. 833-840, 2008.

[13] I. U. Khan, Z. Hameed, Y. Yu, T. Islam, Z. Sheikh, and S. U. Khan, "Predicting the acceptance of MOOCs in a developing country: Application of task-technology fit model, social motivation, and self-determination theory," Telemat. Informatics, vol. 35, no. 4, pp. 964-978, 2018.

[14] Lucas, "A Descriptive Model of Information Systems in the Context of the Organization," Proc. ofthe Whart. Conf. Res. Comput. Organ., pp. 27-36, 1973.

[15] W. H. DeLone and E. R. McLean, "Information systems success: The quest for the dependent variable," Inf. Syst. Res., vol. 3, no. 1, pp. 60-95, 1992.

[16] Sugiyono, Metode Penelitian Bisnis, 17th ed. Bandung: Alfabeta, 2013.

[17] N. K. Malhotra and D. F. Birks, Marketing Research: An Applied Approach, vol. 3. 2009.

[18] J. F. Hair, W. C. Black, B. J. Babin, and R. E. Anderson, "Multivariate Data Analysis," Vectors. p. 816, 2010. 